\title{
Photosynthetic capacity and water use efficiency in Ricinus communis (L.) under drought stress in semi-humid and semi-arid areas
}

\author{
CLAUDIANA M. DOS SANTOS ${ }^{1}$, LAURÍCIO ENDRES ${ }^{1}$, VILMA M. FERREIRA ${ }^{1}$, JOSÉ \\ V. SILVA ${ }^{2}$, EDUARDO V. ROLIM ${ }^{1}$ and HUMBERTO C.L. WANDERLEY FILHO ${ }^{1}$ \\ ${ }^{1}$ Laboratório de Fisiologia Vegetal, Centro de Ciências Agrárias, Universidade Federal de Alagoas, \\ Campus Delza Gitaí, BR 104 Norte, Km 85, 57072-900 Rio Largo, AL, Brazil \\ ${ }^{2}$ Laboratório de Fisiologia Vegetal, Universidade Federal de Alagoas, Campus Arapiraca, Av. \\ Manoel Severino Barbosa, s/n, Bom Sucesso, 57309-005 Arapiraca, AL, Brazil
}

Manuscript received on October 24, 2016; accepted for publication on July 28, 2017

\begin{abstract}
Castor bean is one of the crops with potential to provide raw material for production of oils for biodiesel. This species possess adaptive mechanisms for maintaining the water status when subjected to drought stress. A better understanding these mechanisms under field conditions can unravel the survival strategies used by this species. This study aimed to compare the physiological adaptations of Ricinus communis (L.) in two regions with different climates, the semi-arid and semi-humid subject to water stress. The plants showed greater vapor pressure deficit during the driest hours of the day, which contributed to higher values of the leaf temperature and leaf transpiration, however, the $\mathrm{VPD}_{\text {(leaf-air) }}$ had the greatest effect on plants in the semi-arid region. In both regions, between 12:00 p.m. and 2:00 p.m., the plants presented reduction in the rates of photosynthesis and intracellular $\mathrm{CO}_{2}$ concentration in response to stomatal closure. During the dry season in the semi-arid region, photoinhibition occurred in the leaves of castor bean between 12:00 p.m. and 2:00 p.m. These results suggest that castor bean plants possess compensatory mechanisms for drought tolerance, such as: higher stomatal control and maintenance of photosynthetic capacity, allowing the plant to survive well in soil with low water availability.
\end{abstract}

Key words: Ricinus communis L., water deficit, stomatal control, photoinhibition.

\section{INTRODUCTION}

Drought is a multidimensional phenomenon that includes a water deficit in the soil, increased temperature during the day, reduced nutrient availability and, eventually, increased soil salinity (Oliver et al. 2011). The water deficit is the most

Correspondence to: Laurício Endres

E-mail: lauricioendres@hotmail.com limiting factor affecting the productivity of different cultures globally (Abdallah et al. 2014).

The increasing probability of seasonal droughts and prospects of fresh water scarcity, especially in arid and semi-arid regions, which may cause insufficient rainfall to meet the amount required by crops (FAO 2011). The importance of selecting crops with higher water use efficiency and tolerance to drought, for biomass production under 
future climate conditions, has been suggested by several authors (King et al. 2013).

The castor bean plant (Ricinus communis L.) belongs to the Euphorbiaceae family and is one of the crops with potential to provide raw material for production of biofuels, touted as renewable and less polluting than its fossil competitor, diesel. Moreover, its oil is widely used in the chemical industry (Severino et al. 2012). Castor bean is produced mainly in India, China, Brazil, and Mozambique, leading a worldwide production exceeding one million tons (FAOSTAT 2013). This species tolerates drought stress quite well, becoming a viable crop for the semi-arid region of Brazil, where there are few profitable agricultural alternatives (Sausen and Rosa 2010).

The Brazilian semi-arid region is characterized by a negative water balance, with mean annual rainfall of less than $800 \mathrm{~mm}$, mean insolation of $2800 \mathrm{~h}$ year ${ }^{-1}$, mean annual temperatures of $23^{\circ} \mathrm{C}$ to $27^{\circ} \mathrm{C}$, and mean relative air humidity around $50 \%$ (Moura and Angelotti 2008).

These weather conditions are ideal characteristics for the castor bean crop that develops with an mean temperature between $20^{\circ}$ and $30^{\circ} \mathrm{C}$, high insolation, requiring between 2000 and $3800^{\circ} \mathrm{C}$ units of degree-days, and low relative air humidity of less than $60 \%$ (Beltrão and Azevedo 2007). This culture ideal production range requires rainfall ranging between 750 and $1500 \mathrm{~mm}$, with a minimum of 600 to $750 \mathrm{~mm}$ during the entire cycle (Barros Junior et al. 2008).

In soil water stress situations, plants show adaptive mechanisms that allow them to survive under these conditions. Stomatal closing is the first line of defense against dehydration. Thus, regulation of stomatal conductance is a key phenomenon in plants for the prevention of dehydration during stress (Broeckx et al. 2014, Lawlor and Tezara 2009). Drought stress and consequent stomatal closure leads the plant excess energy exposure, which, if not safely dissipated, can cause over excitation of at the reaction center of photosystem PSII reaction centers (Pinheiro and Chaves 2011), leading to photoinhibition (Takahashi and Badger 2011).

Some of the physiological mechanisms for drought tolerance in castor bean plants were observed in plants grown in controlled environments. Among those mechanisms, we can highlight an efficient stomatal control, greater conservation capacity of $\mathrm{CO}_{2}$ fixation under drought stress (Freitas et al. 2011, Sausen and Rosa 2010), and water use efficiency (Barros Junior et al. 2008). These results are promising, however, information is scarce on experiments under field conditions to better understand the physiological mechanisms, and their interactions with climate factors under temporary drought, in castor beans plants.

The objective of the study presented here was to evaluate the physiological adaptations of Ricinus communis (L.) to two environmental conditions, semi-humid and semi-arid, which are subject to water stress, in Northeastern Brazil.

\section{MATERIALS AND METHODS}

\section{DESCRIPTION OF THE STUDY AREA AND} CLIMATOLOGICAL CHARACTERIZATION

The studies of castor bean plant (Ricinus communis L.), were conducted in two distinct regions of the Alagoas State, the variety BRS-188/Paraguaçu was used in this study. One region is located in the Rio Largo city, in the Florest zone, a region of the Coastal Plains $\left(09^{\circ} 27^{\prime} \mathrm{S}\right.$ and $35^{\circ} 49^{\prime} \mathrm{W}$, mean altitude of $127 \mathrm{~m}$ ). The region is characterized by a semi-humid tropical climate with a rainy season between April and August and a dry season from September to February (spring-summer), with mean rainfall of approximately $1818 \mathrm{~mm}_{\text {year }}{ }^{-1}$ (Souza et al. 2005).

The second study area was the Igaci city, in the Agreste (09 $33^{\prime} \mathrm{S}$ and $36^{\circ} 38^{\prime} \mathrm{W}$, altitude $240 \mathrm{~m}$ ), which has a type of semi-arid tropical climate, with 
a well-defined rainy season between the months of April to August and a dry period during the summer months. This region has a mean rainfall of 740.51 mm (CPTEC 2016).

The temperature and rainfall during the experimental period were obtained from an automatic weather station installed in a open grassed area about $500 \mathrm{~m}$ from the experimental area in the Forest Zone and from weather station in DNOS Arapiraca about $15 \mathrm{~km}$ from the experimental area in the Agreste. The soil water storage and field capacity and actual evapotranspiration were obtained from CPTEC (CPTEC 2016).

The study was conducted in October, month of dry season in both regions. In this month, the semihumid region had an average rainfall of $40.9 \mathrm{~mm}$ and an average temperature of $24.8^{\circ} \mathrm{C}$, in the semiarid region precipitation was lower, with an average of $17.6 \mathrm{~mm}$ and a higher average temperature of $27^{\circ} \mathrm{C}$ (Figure 1a). The actual evapotranspiration (AET) was higher in October in the semi-humid region, with an average of $4.24 \mathrm{~mm} \mathrm{day}^{-1}$, and smaller in the semi-arid region with AET of 1.2 $\mathrm{mm} \mathrm{day}^{-1}$ (Figure 1b). Soil water deficit occurred from the month of September, which characterized temporary drought in the period of the study in that area. In the semi-humid region, soil water deficit appears between October and November (Figure 1c).

For the study, castor bean seeds were germinated in a greenhouse. When approximately two months old, the seedling were transplanted to the field, using $3 \times 2 \mathrm{~m}$ spacing, totaling 300 plants in each region. During transplanting all plants received basic fertilization, consisting of $200 \mathrm{~g}$ per plant of the formula 12-12-12 (N-P-K). Weed and soil pest control was carried out when necessary. The experimental design was completely randomized, two locals and one period, with ten repetitions, one plant was considered an experimental unit. The plants with five months old were randomly chosen and evaluated in the same week in both regions, physiological variables were measured with daily curve: gas exchange and Chlorophyll a fluorescence.

\section{MEASUREMENTS OF GAS EXCHANGE}

Gas exchange measurements were taken every $2 \mathrm{~h}$ (always in the same leaf), between 8:00 a.m. and 4:00 p.m, throughout the day. Fully expanded leaves of the third pair from the apex of ten different plants were marked.

The gas exchange measurements were performed with a portable infrared $\mathrm{CO}_{2}$ analyzer (IRGA), ADC, Bioscientific Ltd, Hoddesdon, UK, with natural light. The following variables were evaluated: photosynthetic rate $\left(\mathrm{P}_{\mathrm{N}}\right)$, transpiration rate $(\mathrm{E})$, stomatal conductance $\left(\mathrm{g}_{\mathrm{s}}\right)$, intercellular $\mathrm{CO}_{2}$ concentrations inside the leaf $\left(\mathrm{C}_{\mathrm{i}}\right)$, leaf temperature (LT), and air chamber relative humidity the $(\mathrm{RH})$. Concentration of $\mathrm{CO}_{2}$ inside the chamber, air humidity, and temperature fluctuated according to environmental conditions. With the values of $\mathrm{P}_{\mathrm{N}}, \mathrm{E}, \mathrm{g}_{\mathrm{s}}$ and $\mathrm{C}_{\mathrm{i}}$ we calculated, respectively, the instantaneous water use efficiency given by the ratio $\left(\mathrm{P}_{\mathrm{N}} / \mathrm{E}=\mathrm{WUE}\right)$, the intrinsic water use efficiency given by the ratio $\left(\mathrm{P}_{\mathrm{N}} / \mathrm{g}_{\mathrm{s}}=\mathrm{WUE}_{\mathrm{i}}\right)$, and the instantaneous carboxylation efficiency $\left(\mathrm{P}_{\mathrm{N}}\right.$ /Ci).

The vapor pressure deficit between leaf and air, $\mathrm{VPD}_{\text {(leaf-air) }}$, throughout the day was obtained by calculating the difference between saturation (es) and real (e) air pressure according to FAO (1991), using measurements of the leaf temperature ( $\mathrm{Tl}$ ) and relative humidity $(\mathrm{RH})$ in the chamber as follows: $\mathrm{VPD}_{\text {(leaf-air) }}=(\mathrm{es}-\mathrm{e})$ in $\mathrm{kPa}$. $V P D($ leaf - air $)=e s-e=\left[0.6108 \exp \left(\frac{17.27 . T l}{237.3+T l}\right)\right]-\left(\frac{e s-U R}{100}\right)$

CHLOROPHYLL A FLUORESCENCE ANALYSIS AND CHLOROPHYLL CONTENT

The photochemical efficiency of photosynthesis was obtained through by evaluation of the 

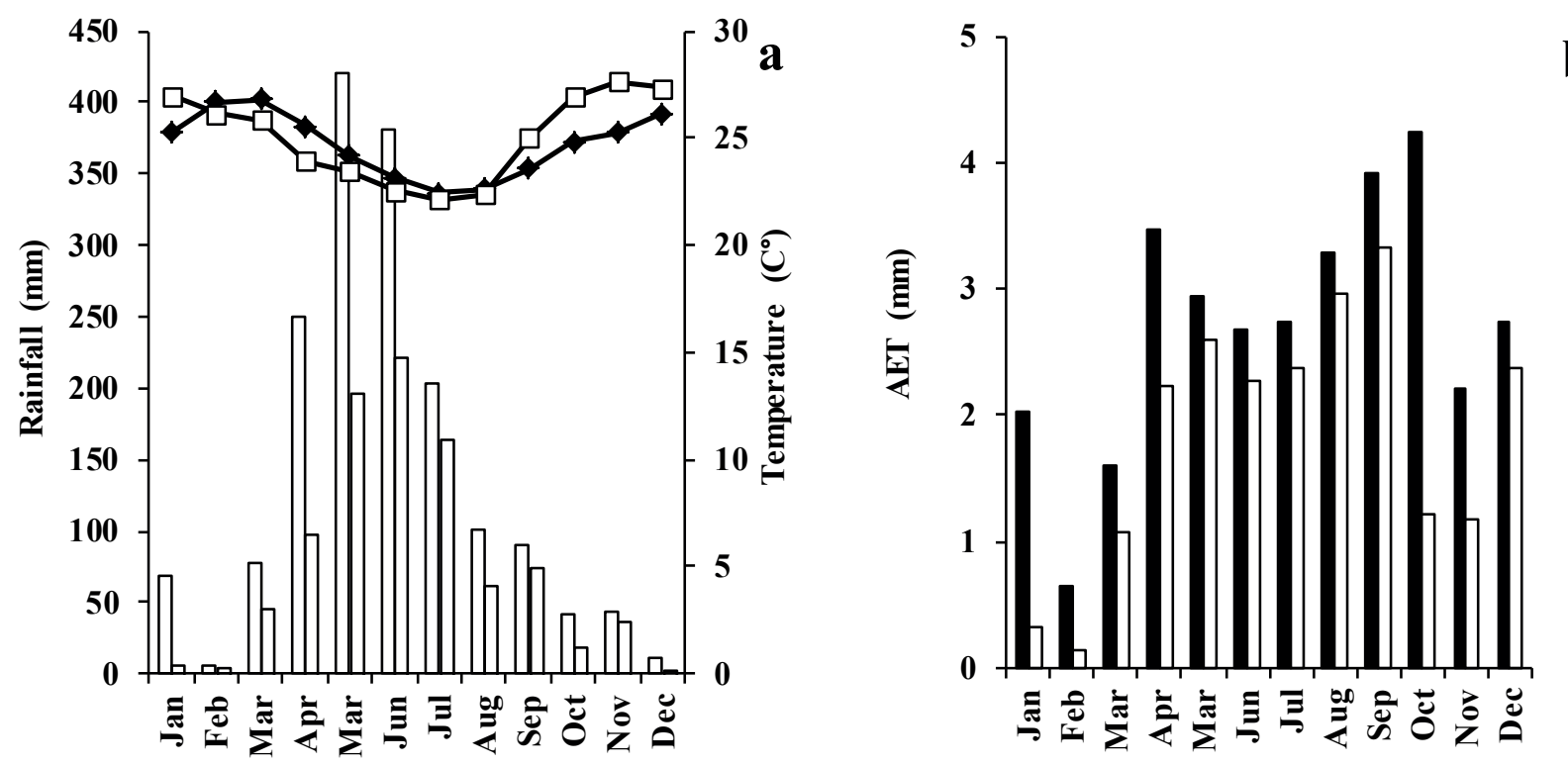

b

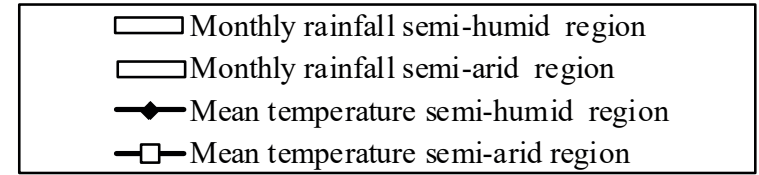

- Actual evapotranspiration semi-humid region

$\square$ Actual evapotranspiration semi-arid region
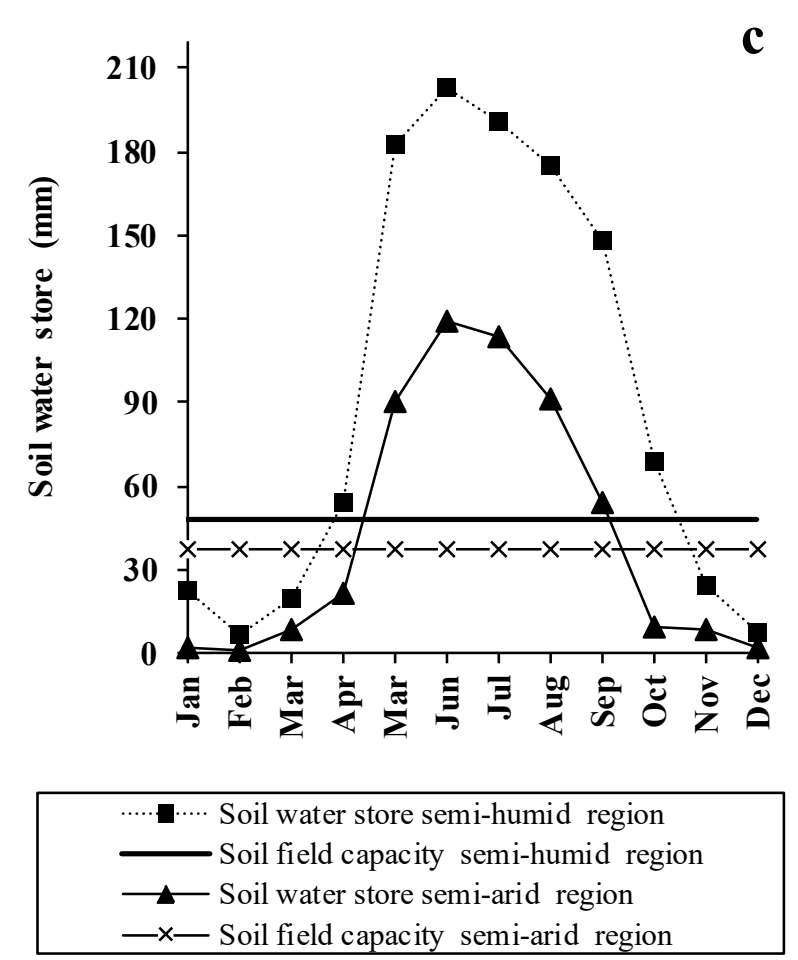

Figure 1 - Climatic characteristics: Total monthly rainfall and mean temperatures (a), actual evapotranspiration, AET, (b) and soil water store (c) (horizontal barre presents soil field capacity) in semi-arid and semi-humid region of Brazil. Source: AGRITEMPO (2016). 
chlorophyll a fluorescence on the same leaves for which the gas exchange was evaluated, using modulated fluorometer 051-FL (Opti-Sciences, Inc., Hudson, NH, USA). The maximum quantum yield of photosystem II $\left(\mathrm{F}_{\mathrm{v}} / \mathrm{F}_{\mathrm{m}}\right)$ was determined, after adapting the leaves to the dark for 30 minutes, by special leaf clips. Measurements were performed after saturating light pulses of $1 \mathrm{~s}$, to promote the closing of PSII reaction centers, according to the method described by Maxwell and Johnson (2000).

The estimated chlorophyll content (SPAD unit) was determined using a chlorophyllometer SPAD502 (Minolta Corp., Ramsey, NJ, USA). Three readings were considered for each experimental unit. The SPAD unit corresponds to the green content in the leaf, and its value is equivalent to the amount of light transmitted by the leaf in two wavelength regions of red and infrared, the amount of red light absorbed indicates the amount of chlorophyll, whereas the amount of light absorbed near the infrared serves as an internal reference to off set the thickness of the leaf (Nauš et al. 2010).

\section{STATISTICAL ANALYSIS}

Data were analyzed separately by variance analysis (F-Test), and jointly by correlation analysis Pearson (r). The data for $\mathrm{VPD}_{\text {(leaf-air) }}$, stomatal conductance, photosynthesis, and WUE $_{i}$ were subjected to regression analysis. The SPAD unit of plants in both environments was compared by the t-test at $5 \%$. For exploratory data analysis, the average and standard error were estimated for each variable.

\section{RESULTS}

\section{DIURNAL VARIATION OF GAS EXCHANGE}

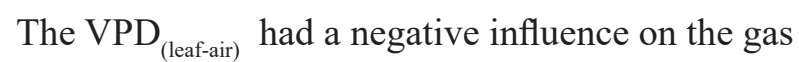
exchange of the castor bean plants. The VPD (leaf-air) $_{\text {. }}$ was higher at 2:00 p.m. with an average of $6.1 \mathrm{KPa}$ in the semi-humid region plants, and at 12:00 p.m. in the semi-arid plants, with an average of $5.2 \mathrm{KPa}$ (Figure 2a). In general, the larger values in $\mathrm{VPD}_{\text {(leaf- }}$ air) were associated with a reduction in stomatal conductance (Figure 3a).

Plants of the semi-arid region suffered a greater effect of the $\mathrm{VPD}_{\text {(leaf-air) }}$ on stomatal control, in this region plants kept stomata partially open, up to 0.6 mol m $\mathrm{m}^{-2} \mathrm{~s}^{-1}$, while in the semi-humid region they reached values close to $1 \mathrm{~mol} \mathrm{~m}^{-2} \mathrm{~s}^{-1}$ (Figure 3a).

A greater vapor pressure deficit was observed during the driest hours of the day which contributed to higher values of the leaf temperature and leaf transpiration. In addition, in the semi-arid region we found a strong correlation between the VPD air) with leaf temperature at 12:00 p.m. $\left(0.96^{* *}\right)$, and the opposite with transpiration $\left(-0.66^{*}\right)$, stomatal conductance $\left(-0.65^{*}\right)$, and photosynthesis $\left(-0.66^{*}\right)$ (Table II), which did not occur in the semi-humid region (Table I).

Leaf temperature was in average close to $30^{\circ} \mathrm{C}$, in the early morning, in castor bean leaves in both regions. The highest average in leaf temperature was observed at 2:00 p.m., $46^{\circ} \mathrm{C}$, in semi-humid plants, and at $12: 00,39^{\circ} \mathrm{C}$, in plants in the semiarid region (Figure $2 \mathrm{~b}$ ).

Stomatal conductance was $22 \%$ lower early in the morning, at 8:00 a.m., in the semi-arid region when compared to plants in the more humid region (Figure 2c). The lowest values of stomatal conductance were found in the afternoon, between 12:00 and 4:00 p.m., the same pattern of reduction was observed in plants of both regions (Figure 2c). Always stomatal conductance had a strong influence on transpiration, as can be seen by the positive correlation between the parameters (Tables I and II). In the semi-humid region, this correlation was maximum at 12:00 p.m. (0.97**), decreasing in the afternoon (Table I). In the semi-arid region the correlation remains high in the afternoon $\left(0.96^{* *}\right)$ at 4:00 p.m.

Leaf transpiration, generally, showed peaks at 14:00 in the semi-humid region and at 12:00 p.m. in the semi-arid region (Figure $2 d$ ). In the semi-humid region, transpiration showed positive 

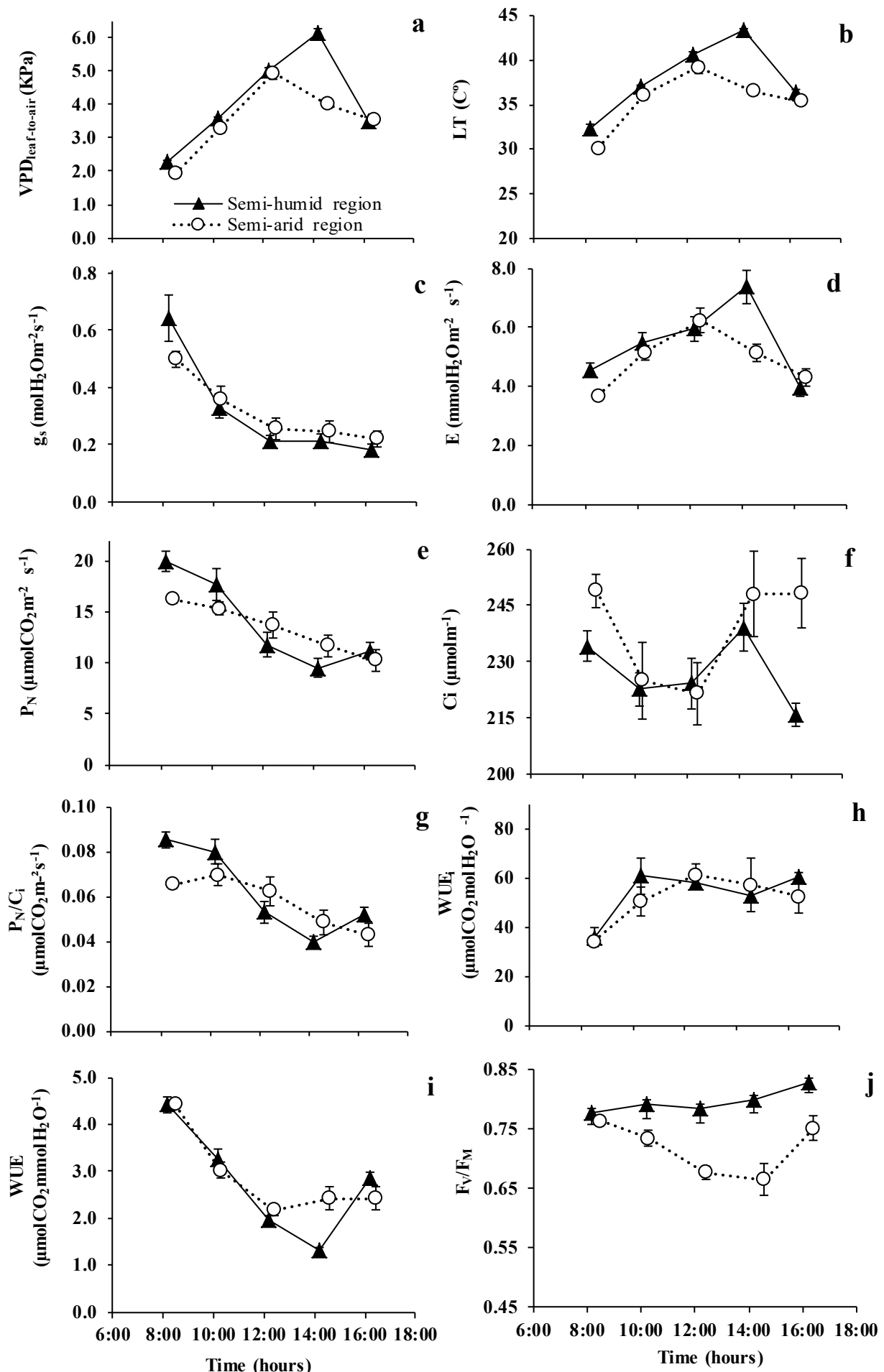

Figure 2 - Diurnal variations of leaf-to-air vapor pressure deficit (a), leaf temperature (b), stomatal conductance (c), transpiration (d), net photosynthesis rate (e), internal concentration of $\mathrm{CO}_{2}(\mathbf{f})$, instantaneous carboxilation efficiency (g), intrinsic water-use efficiency (h) and instantaneous water-use efficiency (i) and maximum photochemical efficiency of PSII (j) in castor bean leaves at different times cultivated in field under soil water stress conditions in semi-arid and semi-humid region of Brazil. Each point represents the mean of 10 plants, and bars indicate standard error. 

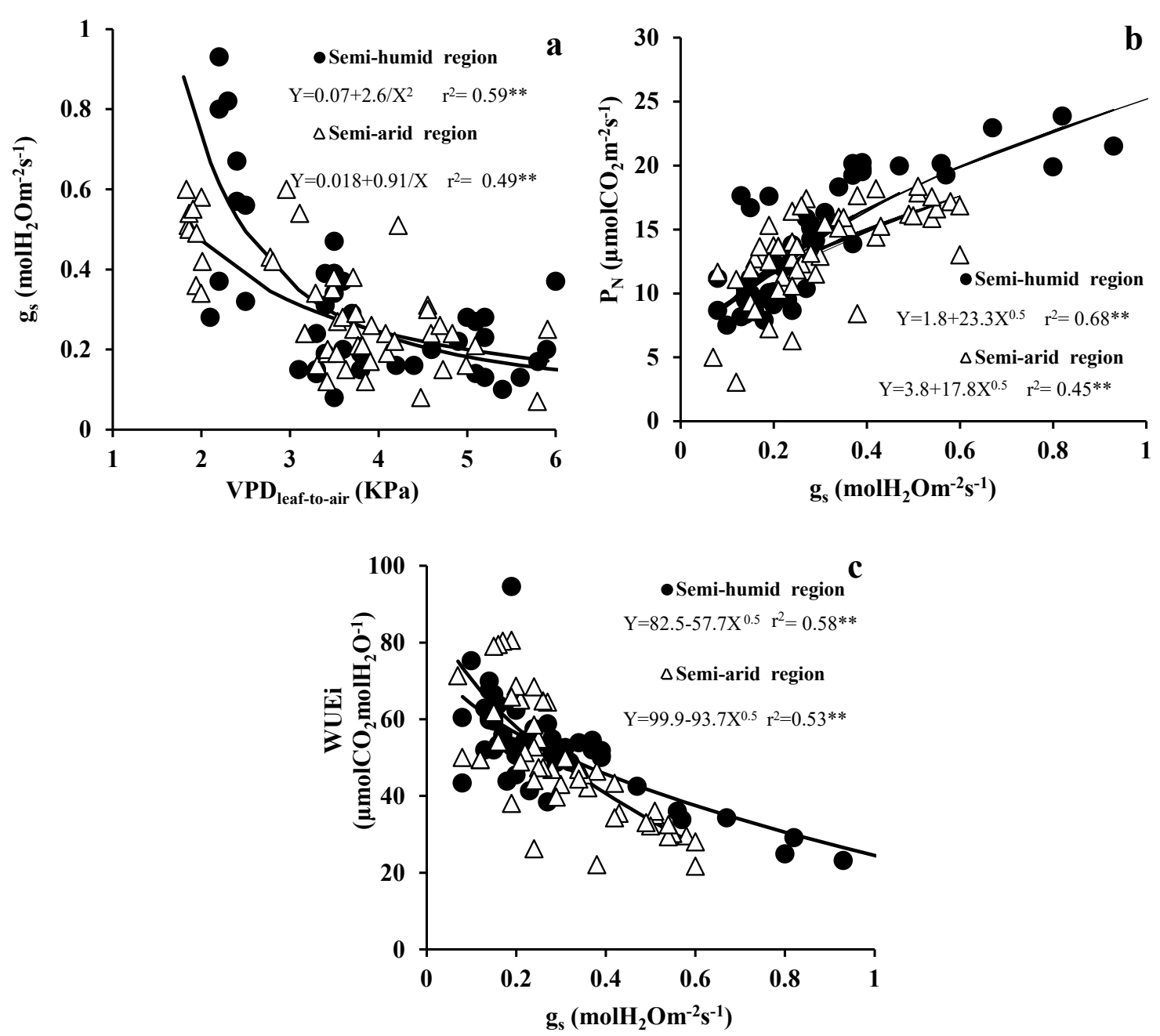

Figure 3 - Stomatal conductance $\left(\mathrm{g}_{\mathrm{s}}\right)$ versus leaf-to-air vapor pressure deficit $\left(\mathrm{VPD}_{\text {leaf-to-air }}\right)(\mathbf{a})$, net photosynthetic rate (b) and intrinsic water-use efficiency $\left(\mathrm{WUE}_{\mathrm{i}}\right)(\mathbf{c})$ in castor bean (Ricinus communis L.) cultivated in field conditions in semi-arid and semi-humid region of Brazil.

correlation with stomatal conductance $\left(0.9^{* *}\right)$ and carboxylation efficiency, $\mathrm{P}_{\mathrm{N}} / \mathrm{C}_{\mathrm{i}}(0.64 *)$, and no correlation with $\mathrm{VPD}_{\text {(leaf-air) }}$ (Table I).

These correlations were particularly expressive in the hottest time of the day (12:00 p.m.), in the semi-arid region. We observed that transpiration had a positive correlation with $\mathrm{g}_{\mathrm{s}}(0.92 * *)$, photosynthesis $\left(0.89^{* *}\right), \mathrm{P}_{\mathrm{N}} / \mathrm{C}_{\mathrm{i}}\left(0.68^{* *}\right)$, and inversely with intrinsic water use efficiency, WUEi $\left(-0.78^{* *}\right)$, leaf temperature $(-0.64 *)$, and $\mathrm{VPD}_{\text {(leaf-air) }}$ $\left(-0.66^{*}\right)$ (Table II).

Photosynthetic rates were higher in the morning, with maximum photosynthesis values at 8:00 a.m., $20 \mu \mathrm{mol} \mathrm{m} \mathrm{m}^{-2} \mathrm{~s}^{-1}$ in plants in the semihumid region, and $16.2 \mu \mathrm{mol} \mathrm{m} \mathrm{m}^{-2} \mathrm{~s}^{-1}$ in plants in the semi-arid region (Figure 2e), which is equivalent to a $19 \%$ photosynthetic capacity reduction earlier in the day in plants of the semi-arid region, when compared to the semi-humid region. In this time, the photosynthesis presented a positive correlation with the stomatal conductance above $0.60 *$ in plants in both regions (Tables I and II). This correlation breaks down at 12:00 p.m. in the semihumid region (Table I) and at 4:00 p.m. in the semiarid region (Table II). 
TABLE I

Pearson correlation coefficients at different times, between physiological variables: leaf temperature (LT), transpiration

(E), stomatal conductance $\left(\mathrm{g}_{\mathrm{s}}\right)$, net photosynthetic rate $\left(\mathrm{P}_{\mathrm{N}}\right)$, instantaneous carboxylation efficiency $\left(\mathrm{P}_{\mathrm{N}} / \mathrm{C}_{\mathrm{i}}\right)$, internal concentration of $\mathrm{CO}_{2}\left(\mathrm{C}_{\mathrm{i}}\right)$, intrinsic water-use efficiency $(\mathrm{WUE})$, instantaneous water-use efficiency (WUE), maximum photochemical efficiency of PSII $\left(\mathrm{F}_{\mathrm{v}} / \mathrm{F}_{\mathrm{m}}\right)$ and leaf-to-air vapor pressure deficit (VPD $\left.{ }_{\text {leaf-to-air }}\right)$, in castor bean (Ricinus communis L.) cultivated in field conditions in semi-humid region of Brazil.

\begin{tabular}{|c|c|c|c|c|c|c|c|c|c|}
\hline Variables & $\mathbf{E}$ & $\mathrm{g}_{\mathrm{s}}$ & $\mathbf{P}_{\mathrm{N}}$ & $\mathbf{P}_{\mathrm{N}} / \mathrm{C}_{\mathrm{i}}$ & $\mathbf{C i}$ & WUE $_{i}$ & WUE & Fv/Fm & VPD \\
\hline & \multicolumn{9}{|c|}{ Semi-humid region } \\
\hline & \multicolumn{9}{|c|}{$8: 00 h$} \\
\hline LT & \multirow[t]{9}{*}{$0.62 *$} & 0.05 & 0.31 & 0.32 & 0.06 & -0.19 & -0.56 & 0.35 & $0.66^{*}$ \\
\hline $\mathbf{E}$ & & $0.64 *$ & $0.76^{* *}$ & $0.68 * *$ & 0.35 & $-0.75^{*}$ & -0.54 & -0.43 & 0.36 \\
\hline $\mathrm{g}_{\mathrm{s}}$ & & & $0.82 * *$ & 0.57 & $0.71 *$ & $-0.96 * *$ & 0.05 & -0.44 & -0.45 \\
\hline $\mathbf{P}_{\mathrm{v}}$ & & & & $0.92 * *$ & 0.40 & $-0.75^{*}$ & 0.12 & -0.22 & -0.14 \\
\hline$P_{N} / C_{i}$ & & & & & 0.01 & -0.52 & 0.14 & 0.04 & 0.00 \\
\hline $\mathbf{C i}$ & & & & & & $-0.71^{*}$ & -0.03 & $-0.70^{*}$ & -0.37 \\
\hline WUE $_{i}$ & & & & & & & 0.17 & 0.54 & 0.28 \\
\hline WUE & & & & & & & & 0.36 & $-0.76^{* *}$ \\
\hline \multirow[t]{2}{*}{ Fv/Fm } & & & & & & & & & -0.01 \\
\hline & \multicolumn{9}{|c|}{ 12:00h } \\
\hline LT & \multirow[t]{9}{*}{0.10} & -0.11 & 0.22 & 0.12 & 0.21 & 0.39 & 0.20 & -0.00 & $0.98 * *$ \\
\hline $\mathbf{E}$ & & $0.97 * *$ & 0.51 & $0.64 *$ & -0.21 & -0.48 & -0.22 & -0.09 & 0.14 \\
\hline $\mathrm{g}_{\mathrm{s}}$ & & & 0.49 & $0.65 *$ & -0.27 & -0.54 & -0.23 & -0.14 & -0.06 \\
\hline $\mathbf{P}_{\mathrm{N}}$ & & & & $0.93 * *$ & 0.21 & 0.44 & $0.70^{*}$ & 0.08 & 0.15 \\
\hline $\mathbf{P}_{\mathbf{v}} / \mathbf{C}_{\mathrm{i}}$ & & & & & -0.14 & 0.19 & 0.48 & 0.01 & 0.10 \\
\hline $\mathbf{C i}$ & & & & & & 0.57 & 0.52 & 0.22 & 0.12 \\
\hline $\mathbf{W U E}_{i}$ & & & & & & & 0.05 & 0.23 & 0.29 \\
\hline WUE' & & & & & & & & 0.22 & 0.08 \\
\hline \multirow[t]{2}{*}{ Fv/Fm } & & & & & & & & & -0.00 \\
\hline & \multicolumn{9}{|c|}{ 16:00h } \\
\hline LT & 0.50 & 0.00 & -0.25 & -0.36 & 0.53 & -0.18 & $-0.93 * *$ & 0.49 & $0.99 * *$ \\
\hline $\mathbf{E}$ & & $0.72 *$ & 0.67 & 0.54 & $0.62 *$ & -0.26 & -0.38 & -0.11 & 0.44 \\
\hline$g_{s}$ & & & $0.80 * *$ & $0.70^{*}$ & 0.46 & $-0.67 *$ & 0.12 & -0.18 & -0.06 \\
\hline $\mathbf{P}_{\mathrm{N}}$ & & & & $0.97 * *$ & 0.09 & -0.14 & 0.41 & -0.00 & -0.30 \\
\hline$P_{N} / C_{i}$ & & & & & -0.11 & -0.03 & 0.55 & $-0.62 *$ & -0.39 \\
\hline $\mathbf{C i}$ & & & & & & -0.48 & -0.65 & 0.29 & 0.44 \\
\hline WUE $_{i}$ & & & & & & & -0.39 & -0.39 & -0.14 \\
\hline WUE & & & & & & & & -0.50 & $-0.91 * *$ \\
\hline Fv/Fm & & & & & & & & & 0.51 \\
\hline
\end{tabular}

* and ** significance of the correlation coefficient on the $\mathrm{P}<0.05$ and $\mathrm{P}<0.01$ level, respectively.

Correlation based on data $(n=10)$.

Throughout the day, we observed a reduction in the photosynthesis rate in plants in both regions, with recovery in the late afternoon, only in plants of the semi-humid region (Figure 2e). In the semihumid region, photosynthesis appears to be more constant over a wide range of stomatal conductance (Figure 3b).

Intracellular $\mathrm{CO}_{2}$ concentration $\left(\mathrm{C}_{\mathrm{i}}\right)$ was higher early in the morning and, especially, late in the afternoon in the semi-arid plants (Figure 2f), which negatively affected the $\mathrm{P}_{\mathrm{N}} / \mathrm{C}_{\mathrm{i}}$ in those periods (Fig. $2 \mathrm{~g})$. Ci relation was negative with $\mathrm{P}_{\mathrm{N}}(-0.70 *), \mathrm{P}_{\mathrm{N}} /$ $\mathrm{C}_{\mathrm{i}}\left(-0.84^{* *}\right), \mathrm{WUE}_{\mathrm{i}}\left(-0.67^{*}\right)$, and WUE $\left(-0.72^{* *}\right)$ at 16:00 in the semi-arid region (Table II), this did not occur in the semi-humid region.

Intrinsic water-use efficiency (WUE $_{\mathrm{i}}$ in castor bean leaves tended to increase throughout the day (Figure $2 \mathrm{~h}$ ) as the stomatal conductance was reduced (Figure 3c). The same occurred with WUE (Figure 2i), but with a sharper reduction at 2:00 
TABLE II

Pearson correlation coefficients at different times, between physiological variables: leaf temperature (LT), transpiration

(E), stomatal conductance $\left(g_{s}\right)$, net photosynthetic rate $\left(P_{N}\right)$, instantaneous carboxylation efficiency $\left(P_{N} / C_{i}\right)$, internal concentration of $\mathrm{CO}_{2}\left(\mathrm{C}_{\mathrm{i}}\right)$, intrinsic water-use efficiency (WUE $)$, instantaneous water-use efficiency (WUE), maximum photochemical efficiency of PSII $\left(\mathrm{F}_{\mathrm{v}} / \mathrm{F}_{\mathrm{m}}\right)$ and leaf-to-air vapor pressure deficit (VPD $\left.{ }_{\text {leaf-to-air }}\right)$, in castor bean (Ricinus communis $\mathbf{L}$.) cultivated in field conditions in semi-arid of Brazil.

\begin{tabular}{|c|c|c|c|c|c|c|c|c|c|}
\hline Variables & $\mathbf{E}$ & $\mathbf{g}_{\mathrm{s}}$ & $\mathbf{P}_{\mathrm{N}}$ & $P_{N} / C_{i}$ & Ci & WUE $_{i}$ & WUE & Fv/Fm & VPD \\
\hline & \multicolumn{9}{|c|}{ Semi-arid region } \\
\hline & \multicolumn{9}{|c|}{$8: 00 h$} \\
\hline LT & -0.01 & -0.45 & $-0.68 *$ & -0.40 & -0.13 & -0.40 & -0.58 & -0.44 & $0.83 * *$ \\
\hline $\mathbf{E}$ & & $0.86^{* *}$ & 0.43 & 0.06 & 0.39 & -0.85 & -0.59 & 0.09 & -0.04 \\
\hline $\mathrm{g}_{\mathrm{s}}$ & & & $0.62 *$ & 0.15 & 0.45 & $-0.93 * *$ & -0.30 & 0.21 & -0.52 \\
\hline $\mathbf{P}_{\mathrm{N}}$ & & & & $0.68 *$ & 0.08 & -0.34 & 0.46 & 0.08 & -0.45 \\
\hline $\mathbf{P}_{\mathrm{N}} / \mathbf{C}_{\mathrm{i}}$ & & & & & $-0.66^{*}$ & 0.07 & 0.55 & -0.02 & -0.03 \\
\hline $\mathbf{C i}$ & & & & & & -0.49 & -0.31 & 0.071 & -0.41 \\
\hline WUE $_{i}$ & & & & & & & 0.55 & -0.15 & 0.45 \\
\hline WUE & & & & & & & & -0.00 & -0.33 \\
\hline \multirow[t]{2}{*}{ Fv/Fm } & & & & & & & & & -0.18 \\
\hline & $2: 00 h$ & & & & & & & & \\
\hline LT & $-0.64 *$ & $-0.66^{*}$ & $-0.72 *$ & $-0.73 *$ & 0.18 & 0.32 & -0.55 & -0.18 & $0.96 * *$ \\
\hline $\mathbf{E}$ & & $0.92 * *$ & $0.89 * *$ & $0.68 * *$ & 0.40 & $-0.78 * *$ & 0.39 & 0.04 & $-0.66^{*}$ \\
\hline $\mathrm{g}_{\mathrm{s}}$ & & & $0.79 * *$ & 0.51 & 0.53 & -0.86 & 0.25 & 0.26 & $-0.65 *$ \\
\hline $\mathbf{P}_{\mathrm{N}}$ & & & & $0.90 * *$ & 0.12 & -0.46 & $0.74 * *$ & -0.04 & $-0.66^{*}$ \\
\hline $\mathrm{P}_{\mathrm{N}} / \mathrm{C}_{\mathrm{i}}$ & & & & & -0.29 & -0.10 & $0.87 * *$ & -0.22 & -0.67 \\
\hline $\mathbf{C i}$ & & & & & & $-0.78 * *$ & -0.33 & 0.36 & 0.18 \\
\hline WUE $_{i}$ & & & & & & & 0.20 & -0.24 & 0.38 \\
\hline WUE & & & & & & & & -0.07 & -0.41 \\
\hline \multirow[t]{2}{*}{ Fv/Fm } & & & & & & & & & -0.17 \\
\hline & 6:00h & & & & & & & & \\
\hline LT & 0.04 & -0.16 & -0.41 & -0.30 & 0.19 & -0.29 & -0.52 & -0.00 & $0.96 * *$ \\
\hline $\mathbf{E}$ & & $0.96 * *$ & 0.39 & 0.30 & 0.07 & -0.50 & -0.21 & 0.46 & -0.11 \\
\hline $\mathrm{g}_{\mathrm{s}}$ & & & 0.37 & 0.23 & 0.18 & -0.52 & -0.18 & 0.49 & -0.31 \\
\hline $\mathbf{P}_{\mathrm{N}}$ & & & & $0.96 * *$ & $-0.70 *$ & 0.49 & 0.77 & $0.63 * *$ & -0.36 \\
\hline $\mathbf{P}_{\mathrm{N}} / \mathbf{C}_{\mathrm{i}}$ & & & & & $-0.84 * *$ & 0.54 & $0.77 * *$ & 0.11 & -0.25 \\
\hline $\mathbf{C i}$ & & & & & & $-0.67 *$ & $-0.72 * *$ & 0.24 & 0.14 \\
\hline $\mathbf{W U E}_{i}$ & & & & & & & $0.90 * *$ & -0.10 & -0.12 \\
\hline WUE & & & & & & & & 0.02 & -0.37 \\
\hline Fv/Fm & & & & & & & & & -0.05 \\
\hline
\end{tabular}

* and ** significance of the correlation coefficient on the $\mathrm{P}<0.05$ and $\mathrm{P}<0.01$ level, respectively.

Correlation based on data $(n=10)$.

p.m. in plants in the semi-humid region, mainly due to increased transpiration (Figure 2d). WUE has a negative relation with $\mathrm{VPD}_{\text {(leaf-air) }}$ early in the morning $\left(-0.76^{* *}\right)$, and late afternoon $(-0.91 * *)$, only in semi-humid region (Table I). In the semiarid region, VPD had no effect on WUE (Table II).

\section{QUANTUM EFFICIENCY OF PHOTOSYSTEM II}

Photosystem II maximum quantum yield of photosystem II, represented by the ratio $\mathrm{F}_{\mathrm{v}} / \mathrm{F}_{\mathrm{m}}$, showed little variation throughout the day in plants in the semi-humid region, averaging $\mathrm{F}_{\mathrm{v}} / \mathrm{F}_{\mathrm{m}}$ from 0.83 to 0.78 (Figure $2 \mathrm{j}$ ). In plants in the semiarid region, the $\mathrm{F}_{\mathrm{v}} / \mathrm{F}_{\mathrm{m}}$ decreased more intensely throughout the day, reaching values of 0.66 around 2:00 p.m. (Figure $2 \mathrm{j}$ ), which meant a reduction of $17.5 \%$ when compared to the semi-humid region. In the late afternoon, we observed a partial recovery of $\mathrm{F}_{\mathrm{v}} / \mathrm{F}_{\mathrm{m}}$ in the semi-arid region, with averages of 0.75 (Fig. 2j), only in this period there was a 
positive correlation $\left(0.63^{* *}\right)$ between $\mathrm{F}_{\mathrm{v}} / \mathrm{F}_{\mathrm{m}}$ and photosynthesis (Table II).

The estimated chlorophyll content of castor bean leaves showed values of 59.8 SPAD unit for the semi-humid region, and 51.0 SPAD unit for the semi-arid region, which is equivalent to a reduction of $17.2 \%$ compared to the region with the highest water availability (Figure 4).

\section{DISCUSSION}

Water deficiency is an important environmental constraint that affects all physiological processes involved in the growth and development of plants. This influence would be a set of responses to drought mainly affecting the mechanism of gas exchanges (Centritto et al. 2009). In this study, we can better understand how these mechanisms work in castor bean plants in two regions very close geographically, but with very different rainfall, the semi-humid and semi-arid, in the dry season, in order to generate information on responses of water loss regulation for carbon gain, and water use efficiency, which are important characteristics for the maintenance of the plant photosynthetic capacity.

Vapor pressure deficit is one of the most important environmental factors for stomatal response. In this study, we observed similar variation of the $\mathrm{VPD}_{\text {(leaf-air) }}$ in plants in both regions, with a peak above $5.0 \mathrm{KPa}$ at 12:00 p.m. At this hour, plants in the semi-arid region showed an inverse correlation between $\mathrm{VPD}_{\text {(leaf-air) }}$ and stomatal conductance, transpiration, and photosynthesis, which must have been influenced by high temperatures and low soil water availability on the site, these factors probably, increased the effect

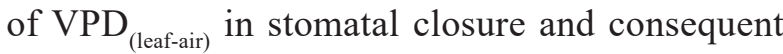
reduction in transpiration to prevent water loss. Similar results were also found in different cultures, such as sugar-apples (Endres 2007), peanuts (Balota et al. 2012), and purging nut (Santos et al.
2013), in which, in studies conducted during the dry season, the authors also found that the increase in vapor pressure deficit in the early afternoon negatively influenced the stomatal conductance in these species.

Increased leaf temperature throughout the day, noted in this study, may indicate that castor bean plants are able to grow in environments with high thermal range. Under high temperature, castor bean plants present biochemical response to adjust their growth, development, and to maintain cellular homeostasis (Ribeiro et al. 2014). This makes castor bean crop a good candidate for agricultural production in tropical regions.

The plants of the semi-arid region started the day with stomatal conductance lower than the plants of the semi-humid region, probably due to the low soil moisture in location. Moreover, the plants of the semi-arid region presented stomatal closure similar the plants semi-humid region during the day, an indication that the stomatal control is an important adaptive mechanism of drought tolerance in this species.

In studies conducted in purging nut belonging to the family Euphorbiaceae (Hsie et al. 2015, Santos et al. 2013). These authors found a direct relationship between stomatal closure with low soil water potential in the morning. Partial closing of the stomata is a known plant tolerance strategy to water stress, because it decreases transpiration rate, preserves leaf water content, reduces the risk of dehydration, and eventual death by desiccation (Peak et al. 2004).

Castor bean plants maintained a stomatal conductance close to $0.2 \mathrm{~mol} \mathrm{~m}^{-2} \mathrm{~s}^{-1}$ from 12:00 p.m. and strong correlation with transpiration in both regions. Similar results were found in castor bean plant experiments in greenhouse (Freitas et al. 2011, Sausen and Rosa 2010), and under salinity (Lima Neto et al. 2014, Sun et al. 2013). These results indicate that this plant has a high stomatal regulation under field conditions, which can reduce 


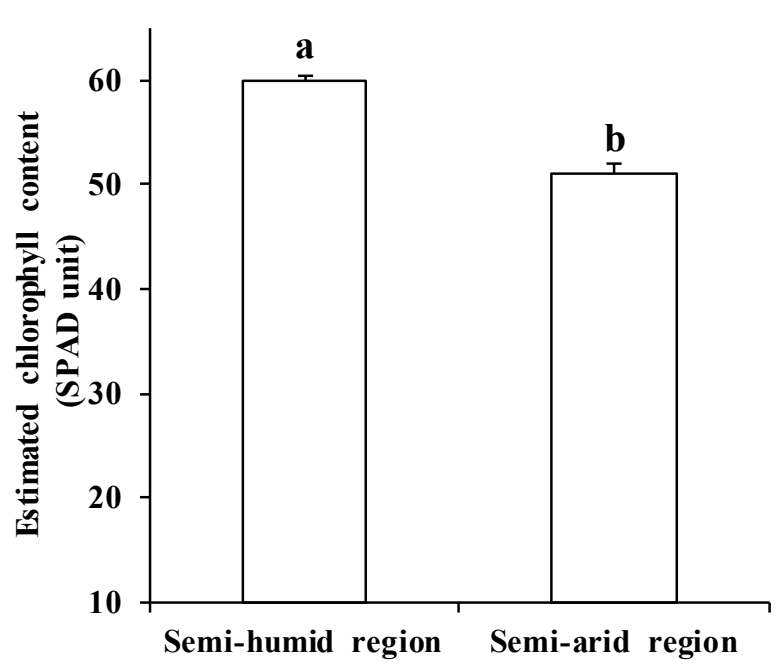

Figure 4 - Estimated chlorophyll content (SPAD unit) in castor bean leaves cultivated in field conditions in semi-arid and semi-humid region of Brazil. Means not assigned by the same letters are significantly different at $\mathrm{P}<0.05$ by t-test $(\mathrm{n}=50$ independent samples).

water loss by transpiration and maintain the water status of the plant (Pinheiro and Chaves 2011). According to Berry et al. (2010), plants with better control of stomatal function are more efficient in water use and have a higher degree of drought tolerance.

Photosynthesis in the leaf of castor bean plants showed a pattern of behavior similar to that of stomatal conductance in both regions, confirmed by the positive relationship of $g_{s}$ and photosynthesis. In addition, plants of the semi-arid region were under increased water stress, confirmed by the already low rate of photosynthesis early in the day, which kept decreasing throughout the day without recovery. Such evidence should be indicative that the plant was under moderate to severe water stress during that period in the semi-arid region. Similar results were found in castor bean plant experiments in greenhouse when subjected to severe water stress (Freitas et al. 2011, Sausen and Rosa 2010).

Photosynthesis depression at midday probably results from the increase in $\mathrm{VPD}_{\text {(leaf-air) }}$ and high temperature (Breshears et al. 2013, Seversike et al. 2013), resulting in stomatal closure (Pinheiro and Chaves 2011, Santos et al. 2013), or possibly due to direct damage from water stress on the photosynthetic metabolism (Endres et al. 2010), which could be seen by the reduction of $\mathrm{P}_{\mathrm{N}} / \mathrm{C}_{\mathrm{i}}$ throughout the day, particularly in the semi-arid region, with significant reduction of $\mathrm{F}_{\mathrm{v}} / \mathrm{F}_{\mathrm{m}}$.

According to Ocheltree et al. (2014), in $\mathrm{C}_{3}$ plants reduction in stomatal conductance is meant to minimize loss of water, however, it also decreases the $\mathrm{CO}_{2}$ diffusion rate, which lowers the $\mathrm{CO}_{2}$ internal concentration leading to decreased efficiency of carbon fixation in plants.

Furthermore, the positive correlation of carboxylation efficiency with transpiration and photosynthesis, and inversely with leaf temperature, of semi-arid plants at 12:00 p.m., indicates that the increase in leaf temperature may have caused damage directly to photosynthetic apparatus photochemical mechanism, which might have reduced the drop on the plant carboxylation efficiency and photosynthesis rate, contributing to the increase in plant photoinhibition during the hottest times of the day. That is, the reduction of carboxylation efficiency and $\mathrm{F}_{\mathrm{v}} / \mathrm{F}_{\mathrm{m}}$, means the occurrence of metabolic damage that may be related to the decrease in activity of the Rubisco enzyme, involved in the fixation process of $\mathrm{CO}_{2}$ and other enzymes related to photosynthesis (Ashraf and Harris 2013). The $\mathrm{P}_{\mathrm{N}} / \mathrm{C}_{\mathrm{i}}$ maybe considered as the estimation of Rubisco activity, informing its limitation under conditions of stress (Niinemets et al. 2009).

The reduction in stomatal conductance was correlated with an increase in the intrinsic water use efficiency in both regions, which indicates that stomatal closure contributed to optimize water use efficiency in plants under stress, which may have enabled plants to absorb carbon by decreasing the loss of water in the hottest part of the day, contributing to photosynthesis maintenance (Broeckx et al. 2014, Roel et al. 2011). We can 
consider in this study $\mathrm{WUE}_{\mathrm{i}}$ as a preventive mechanism, as an immediate effect of water deficiency. From the physiological point of view, the high value of $\mathrm{WUE}_{\mathrm{i}}$ is traditionally seen as a mechanism that provides enhanced productivity and survival in dry environments (Centritto et al. 2009, Gilbert et al. 2011).

Several authors found in different species that the reduction in gs caused an increase in intrinsic water use efficiency, especially, with low soil water availability like in purging nut (Sapeta et al. 2013) and soy (Gilbert et al. 2011). Barros Junior et al. (2008), in study conducted in castor bean plants under drought stress, reports that plants showed high water use efficiency even under stress, which helped in maintaining the biomass production.

Unlike $\mathrm{WUE}_{\mathrm{i}}$, instantaneous water use efficiency decreased throughout the day, in particular during peak hours of transpiration in plants, corresponding to the hottest hours of the day in both regions. These results suggest that a VPD (leaf-air) increase caused a significant boost in transpiration, while photosynthesis tends to decrease with stomatal closure, a fact confirmed by Lima Neto et al. (2015) in castor bean plants under drought stress, where they observed a high transpiration rate linked with low photosynthesis.

Plants in the semi-arid region underwent photoinhibition throughout the day with $\mathrm{F}_{\mathrm{v}} /$ $\mathrm{F}_{\mathrm{m}}$ dropping to 0.66 at the hottest times day, indicating that castor bean plants had a dynamic photoinhibition, which must have happened due to over-excitation of photosystem II reaction centers in photosystems in conditions of light excess and response to water stress in the environment (Pimentel 2004). In this case, photoinhibition should not be seen as damage, but as a protective mechanism that allows the dissipation of excess thermal energy (Takahashi and Badger 2011), since photosystems recovered during the late afternoon with the $\mathrm{F}_{\mathrm{v}} / \mathrm{F}_{\mathrm{m}}$ rate near 0.8 in both environments, observed in the early morning.
The combination of dynamic photoinhibition and stomatal closure under high irradiance can be a powerful defense mechanism in $\mathrm{C}_{3}$ plant (Pinheiro and Chaves 2011). In this case, thermic dissipation through different mechanisms, involving the cycle of xanthophylls, D1 proteins, and water-water cycle, compete with the photochemical process for absorbed energy and prevent damage in the photosystem (Roach and Krieger-Liszkay 2014).

In a study of castor bean plants grown under water stress (Shi et al. 2014), and salt stress (Li et al. 2010, Lima Neto et al. 2014, Sun et al. 2013) in a greenhouse, the authors also found values of $\mathrm{F}_{\mathrm{v}}$ / $\mathrm{F}_{\mathrm{m}}$ above 0.7 in plants under stress, which indicated that the plants did not suffer photochemical damage in photosystem II, and showed high photosynthetic efficiency.

Plants of the semi-arid region recorded a 17.2\% SPAD unit reduction when compared to those in the semi-humid, with highest soil water availability, this reduction must be due to water stress. The reduction in the chlorophyll content in leaves provides less energy absorption in the visible region and increases the reflectance in this spectral range (Govender et al. 2009), thus, reducing possible damage to the photosynthetic apparatus. Moreover, the reduction in the SPAD unit can be attributed to changes in water content in the leave (Martínez and Guiamet 2004), or caused by differences in the edafoclimatic conditions (Santos et al. 2013), one example is the plant exposure the intense light, the that increases the transmittance in the leaf, making the chloroplasts migrate from the cell surface to the side walls, reducing the reading of SPAD unit in the leaves (Nauš et al. 2010). On the other hand, Shi et al. (2014) found that the estimation of chlorophyll was unchangedin castor bean leaves under water stress in a controlled environment. 


\section{CONCLUSIONS}

Castor bean plants use a similar gas exchange mechanism in the semi-humid and semi-arid regions, confirming that this culture survives well in soil with low water availability, through the use of compensatory mechanisms of drought tolerance, such as: stomatal closure, maintenance of photosynthetic capacity, and integrity of the photosynthetic apparatus.

The mechanism of the stomatal closure, in order to restrict water loss by transpiration, can be considered an adaptive strategy used by castor bean plants to limit water loss under drought stress, which helps in crop establishment in semi-arid regions.

\section{ACKNOWLEDGMENTS}

This work was financially supported by the Fundação de Amparo à Pesquisa do Estado de Alagoas (FAPEAL) and the Conselho Nacional de Desenvolvimento Científico e Tecnológico (CNPq).

\section{REFERENCES}

ABDALLAH NA, MOSES V AND PRAKASH CS. 2014. The impact of possible climate changes on developing countries. GM Crops \& Food 5: 77-80.

ASHRAF M AND HARRIS PJC. 2013. Photosynthesis under stressful environments: An overview. Photosynthetica 51: 163-190

BALOTA M, MCGRATH S, ISLEIB TG AND TALLURY S. 2012. Transpiration Response to Vapor Pressure Deficit in Field Grown Peanut. Peanut Sci 39: 53-61.

BARROS JUNIOR G, GUERRA HOC, CAVALCANTI MLF AND LACERDA RD. 2008. Consumo de água e eficiência do uso para duas cultivares de mamona submetidas a estresse hídrico. R Bras Eng Agríc Ambiental 12: 350-355.

BELTRÃO NEM AND AZEVEDO DMP. 2007. Fitologia. In: Azevedo DMP and Beltrão NEM (Eds), O Agronegócio da mamona no Brasil, $2^{\mathrm{a}}$ ed., Brasília: Embrapa Informação Tecnológica, p. 116-137.

BERRY JA, BEERLING DJ AND FRANKS PJ. 2010. Stomata: key players in the earth system, past and present. Curr Opin Plant Biol 13: 232-239.
BRESHEARS DD, ADAMS HD, EAMUS D, MCDOWELL NG, LAW DJ, WILL RE, WILLIAMS PA AND ZOU CB. 2013. The critical amplifying role of increasing atmospheric moisture demand on tree mortality and associated regional dieoff OPINION ARTICLE. Front Plant Sci 4: 266.

BROECKX LS, FICHOT R, VERLINDEN MS AND CEULEMANS R. 2014. Seasonal variations in photosynthesis, intrinsic water-use efficiency and stable isotope composition of poplar leaves in a short-rotation plantation. Tree Physiol 34: 1-14.

CENTRITTO M, LAUTERI MMC AND SERRA JR. 2009. Leaf gas exchange, carbon isotope discrimination, and grain yield in contrasting rice genotypes subjected to water deficits during the reproductive stage. J Exp Bot 60: 23252339.

CPTEC - CENTRO DE PREVISÕES DE TEMPO E ESTUDOS CLIMÁTICOS. 2016. Disponível em: <http:// www.cptec.inpe.br>. Acessado em 03 de Fevereiro de 2016.

ENDRES L. 2007. Daily and seasonal variation of water relationship in sugar apple (Annona squamosa L.) under different irrigation regimes at semi-arid Brazil. Sci Hortic 113: 149-154.

ENDRES L, SOUZA JL, TEODORO I, MARROQUIM PMG, SANTOS CM AND BRITO JED. 2010. Gas exchange alteration caused by water deficit during the bean reproductive stage. R Bras Eng Agríc Ambiental 14: 11-16.

FAO. 1991. Report on the Expert Consultation on Procedures for Revision of FAO Guidelines for Prediction of Crop Water Requirements. FAO, Rome, 45 p.

FAO. 2011. The state of the world's land and water resources for food and agriculture (SOLAW) - Managing systems at risk. Food and Agriculture Organization of the United Nations, Rome and Earthscan, London, p. 285.

FAOSTAT. 2013. Food and Agriculture Organization of the United Nations FAO STAT website. Available, 2013. From: http://faostat3.fao.org/home/index.html. Accessed on May 08, 2016.

FREITAS CAS, SILVA ARA, BEZERRA FML, LACERDA CF, PEREIRA FILHO JV AND SOUSA GG. 2011. Produção de matéria seca e trocas gasosas em cultivares de mamoneira sob níveis de irrigação. R Bras Eng Agríc Ambiental 15: 1168-1174.

GILBERT ME, ZWIENIECKI MA AND HOLBROOK NM. 2011. Independent variation in photosynthetic capacity and stomatal conductance leads to differences in intrinsic water use efficiency in 11 soybean genotypes before and during mild drought. J Exp Bot 62(8): 2875-2887.

GOVENDER M, DYE PJ, WEIERSBYE IM, WITKOWSKI ETF AND AHMED F. 2009. Review of commonly used remote sensing and ground-based technologies to measure plant water stress. Water S A 35: 741-752. 
HSIE BS, MENDES KR, ANTUNES WC, ENDRES L, CAMPOS MLO, SOUZA FC, SANTOS ND, SINGH B, ARRUDA ECP AND POMPELLI MF. 2015. Jatropha curcas L. (Euphorbiaceae) modulates stomatal traits in response to leaf-to-air vapor pressure deficit. Biomass Bioenergy 81: 273-281.

KING JS ET AL. 2013. The challenge of lignocellulosic bioenergy in a water-limited world. Biosci 63: 102-117.

LAWLOR DW AND TEZARA W. 2009. Causes of decreased photosynthetic rate and metabolic capacity in waterdeficient leaf cells: a critical evaluation of mechanisms and integration of processes. Ann Bot 103: 561-579.

LI G, WAN S, ZHOU J, YANG Z AND QIN P. 2010. Leaf chlorophyll fluorescence, hyperspectral reflectance, pigments content, malondialdehyde and proline accumulation responses of castor bean (Ricinus communis L.) seedlings to salt stress levels Gang. Ind Crops Prod 31: 13-19.

LIMA NETO MC, LOBO AK, MARTINS MO, FONTENELE AV AND SILVEIRA JA. 2014. Dissipation of excess photosynthetic energy contributes to salinity tolerance: A comparative study of salt-tolerant Ricinus communis and salt-sensitive Jatropha curcas. J Plant Physiol 171: 23-30.

LIMA NETO MC, MARTINS MO, FERREIRA-SILVA SL AND SILVEIRA AG. 2015. Jatropha curcas and Ricinus communis display contrasting photosynthetic mechanisms in response to environmental conditions. Sci Agric 72: 260-269.

MARTÍNEZ DE AND GUIAMET JJ. 2004. Distortion of the SPAD 502 chlorophyll meter readings by changes in irradiance and leaf water status. Agronomie 24: 41-46.

MAXWELL K AND JOHNSON GN. 2000. Chlorophyll fluorescence: a pratical guide. J Exp Bot 51: 659-668.

MOURA MSB AND ANGELOTTI F. 2008. Clima. In: Albuquerque ACS and Silva AG (Eds), Agricultura tropical: quatro décadas de inovações tecnológicas, institucionais e políticas. Brasília, DF: Embrapa Informação Tecnológica 2(cap. 3): 411-429.

NAUŠ J, PROKOPOVÁ J, ŘEBÍČEK J AND ŠPUNDOVÁ M. 2010. SPAD chlorophyll meter reading can be pronouncedly affected by chloroplast movement. Photosyn Res 105: 265-271.

NIINEMETS U, DÍAZ-ESPEJO A, FLEXAS J, GALMÉS J AND WARREN CR. 2009. Importance of mesophyll diffusion conductance in estimation of plant photosynthesis in the field. J Exp Bot 60: 2271-2282.

OCHELTREE TW, NIPPERT JB AND PRASAD PVV. 2014. Stomatal responses to changes in vapor pressure deficit reflect tissue-specific differences in hydraulic conductance. Plant Cell Environ 37: 132-139.

OLIVER MJ, GUO L, ALEXANDER DC, RYALS JA, WONE BW AND CUSHMAN JC. 2011. A Sister Group Contrast Using Untargeted Global Metabolomic Analysis Delineates the Biochemical Regulation Underlying
Desiccation Tolerance in Sporobolus stapfianus. Plant Cell 23: 1231-1248.

PEAK D, WEST JD, MESSINGER SM AND MOTT KA. 2004. Evidence for complex, collective dynamics and emergent, distributed computation in plants. PNAS 101: 918-922.

PIMENTEL C. 2004. A relação da planta com a água. Rio de Janeiro: Edur, 191 p.

PINHEIRO C AND CHAVES MM. 2011. Photosynthesis and drought: can we make metabolic connections from available data? J Exp Bot 62: 869-882.

RIBEIRO PR, FERNANDEZ LG, CASTRO RD, LIGTERINK W AND HILHORST WMH. 2014. Physiological and biochemical responses of Ricinus communis seedlings to different temperatures: a metabolomics approach. BMC Plant Biol 14: 1.

ROACH T AND KRIEGER-LISZKAY AK. 2014. Regulation of Photosynthetic Electron Transport and Photoinhibition. Curr Protein Pept Sci 15: 351-362.

ROEL JW, WANEK BW AND HIETZ P. 2011. Stable carbon isotopes in tree rings indicate improved water use efficiency and drought responses of a tropical dry forest tree species. Trees 25: 103-113.

SANTOS CM, VERÍSSIMO V, WANDERLEY-FILHO HCL, FERREIRA VM, CAVALCANTE PGS, ROLIM EV AND ENDRES L. 2013. Seasonal variations of photosynthesis, gas exchange, quantum efficiency of photosystem II and biochemical responses of Jatropha curcas L. grown in semi-humid and semi-arid areas subject to water stress. Ind Crops Prod 41: 203-213.

SAPETA H, COSTA JM, LOURENÇO T, MAROCO J, LINDEE PVD AND OLIVEIRA MM. 2013. Drought stress response in Jatropha curcas: Growth and physiology. Environ Exp Bot 85: 76-84.

SAUSEN TL AND ROSA LMG. 2010. Growth and carbon assimilation limitations in Ricinus communis (Euphorbiaceae) under soil water stress conditions. Acta Bot Bras 24: 648-654.

SEVERINO LS ET AL. 2012. Review on the challenges for increased production of castor. Agron J 104: 853-880.

SEVERSIKE TM, SERMONS SM, SINCLAIR TR, CARTER JR TE AND RUFTY TW. 2013. Temperature interactions with transpiration response to vapor pressure deficit among cultivated and wild soybean genotypes. Physiol Plant 148: 62-73.

SHI G, ZHU-GE F, LIU Z AND LE L. 2014. Photosynthetic responses and acclimation of two castor bean cultivars to repeated drying-wetting cycles. J Plant Interact 9: 783-790.

SOUZA JL, NICÁCIO RM AND MOURA AL. 2014. Global solar radiation measurements in Maceió Brazil. Renew Energy 30: 1203-1220.

SUN Y, NIU G, OSUNA P, GANJEGUNTE G, AULD D, ZHAO L, PERALTA-VIDEA JR AND GARDEA- 
TORRESDEY JL. 2013. Seedling emergence, growth, and leaf mineral nutrition of Ricinus communis L. cultivars irrigated with saline solution. Ind Crops Prod 49: 75-80.
TAKAHASHI S AND BADGER MR. 2011. Photoprotection in plants: a new light on photosystem IIdamage. Trends Plant Sci 16: 53-60. 